\title{
Reduction of negative impact of salts used for winter road maintenance on the environment
}

\author{
Tomas Ratkevičius ${ }^{\mathrm{a}}$, Alfredas Laurinavičius ${ }^{\mathrm{b}}$, Faustina Tuminienè $\dot{e}^{\mathrm{a}}$, Jolita Braduliené $\dot{\mathrm{b}}^{\mathrm{b}}$ \\ ${ }^{a}$ Road Research Institute, Faculty of Environmental Engineering, Vilnius Gediminas technical university, Linkmenu str. 28, LT-08217 Vilnius, Lithuania \\ ${ }^{b}$ Vilnius Gediminas technical university, Sauletekio ave. 11, LT-10223 Vilnius, Lithuania
}

\begin{abstract}
Winter in Lithuania is the most complicated time of the year to ensure the functioning of transport systems. The main factor which impedes a normal operation of the systems is weather conditions making a direct influence on vehicles and infrastructure elements of transport systems. Precipitation, low air temperature, strong wind and other unfavourable weather conditions impede traffic on the roads and streets.

In Lithuania, like in other countries of the world, for the purpose of winter road maintenance (to reduce pavement slipperiness) chemical materials on a basis of chlorides are used $\left(\mathrm{NaCl}, \mathrm{CaCl}_{2}, \mathrm{NaCl}+\mathrm{CaCl}_{2}\right.$ mixes), the annual amount of which spread on the roads and streets of Lithuania comes to 160 thousand tonnes.

Though salts, used for road maintenance, are able to immediately ensure safe traffic conditions, they all have larger or smaller negative impact on the environment which depends on the composition of salts, the amount used and interaction with other environmental components. A negative environmental impact comprises: ground (soil) contamination; water pollution (surface, ground and underground); impact on flora, fauna and human beings; corrosion (of vehicles, roads and reinforced concrete structures); deterioration and deformation of road pavements.

Based on the increasing requirements in the field of traffic safety, environmental protection and ecology it is necessary to search for the most effective and less damaging measures to ensure road maintenance in winter: to improve planning and management of winter road maintenance; to implement modern snow cleaning and ice removal technologies; to put into practice preventive road maintenance measures; to use alternative materials and inhibitors which reduce a negative environmental impact.
\end{abstract}

Keywords: Winter road maintenance; environmental impact; road salt reduction; traffic safety.

\begin{tabular}{|ll|}
\hline Nomenclature \\
$\mathrm{CaCl}_{2}$ & calcium chloride \\
$\mathrm{HN}$ & Hygienic Norm \\
$\mathrm{MPC}$ & maximum permissible concentrations \\
$\mathrm{MgCl}_{2}$ & magnesium chloride \\
$\mathrm{NaCl}$ & sodium chloride \\
VGTU & Vilnius Gediminas technical university \\
\hline
\end{tabular}

\section{Introduction}

Every year Lithuania like other countries in the world faces the problems of road maintenance in winter. Roads require a special care in during winter season since the number of accidents can highly increase if they are not properly maintained. It should be mentioned that different countries have different meteorological and environmental conditions, thus, the methods of winter road maintenance can also differ. For example, in the northern countries (Norway, Finland, other) during winter season the number of temperature transitions over $0^{\circ} \mathrm{C}$ is lower than that in Lithuania which in our country varies from 45 to 85 times per winter season. This meteorological phenomenon causes extremely dangerous traffic conditions due to formation of glazed frost. Analysis of materials used in foreign countries for winter road maintenance (to reduce slipperiness) showed that most countries for the road groups of the highest maintenance level use the chloride-based

Corresponding author: Tomas Ratkevičius. E-mail address: tomas.ratkevicius@vgtu.lt

http://dx.doi.org/10.3846/enviro.2014.165

(C) 2014 The Authors. Published by VGTU Press. This is an open-access article distributed under the terms of the Creative Commons Attribution License, which permits unrestricted use, distribution, and reproduction in any medium, provided the original author and source are credited. 
chemical materials, while for spreading the road groups of lower maintenance level the most popular are friction materials (sand, gravel, chippings, etc.) [1].

Chemical reagents that are used to melt snow and ice on streets and roads are chosen according to the economic indices (acquisition, transportation, stockpiling and storage), and also depending on their physical and chemical properties, such as solubility, eutectic temperature, ice melting kinetics, hygroscopicity, caking [2].

In recent years, in our country from chemical materials able to melt snow and ice on roads the widely used are $\mathrm{NaCl}$, $\mathrm{CaCl}_{2}$ and their mixtures, the use of which during the winter season (November-April) for spreading roads of national significance amounts to 80-85 thousand tonnes and almost twice as much is spread on the streets maintained by local municipalities. Up to $10 \%$ of this amount is comprised by $\mathrm{CaCl}_{2}$ (Fig. 1). Depending on a degree of slipperiness, air temperature, thickness of snow or ice layer and composition of spreading material, during one spread approximately 20 $40 \mathrm{~g} / \mathrm{m}^{2}$ of salt are applied on the road. During winter season the road is spread 80 times on average, and $1 \mathrm{~m}^{2}$ of road account for about $2.5 \mathrm{~kg}$ of salt [3].

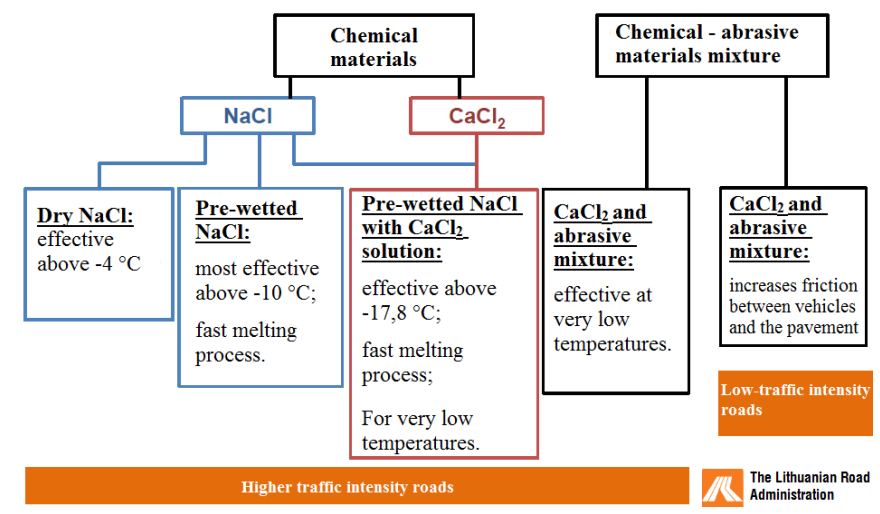

Fig. 1. Slipperiness reduction materials used on the roads of national significance [3]

Though salts, used for road maintenance, are able to immediately ensure safe traffic conditions, they all have larger or smaller negative impact on the environment which depends on the composition of salts, the amount used and interaction with other environmental components. The largest negative impact of salts was determined on the environment in close proximity to the road and comprises: ground (soil) contamination; water pollution (surface, ground and underground); impact on flora, fauna and human beings; corrosion (of vehicles, roads and reinforced concrete structures); deterioration and deformation of road pavements [4].

There are more constantly raising questions than scientific researches accomplished. This requires the economically attractive solutions of two problems - road safety and environmental pollution.

\section{The currently valid requirements to road salts in Lithuania}

Lithuania has no legal acts regulating the salt spreading rates (amounts) in winter, they depend on the maintenance level of the road to be spread (significance in the road network and traffic volume) and meteorological conditions (pavement and air temperature, wind direction and intensity, thickness of snow or ice cover). In winter a different type of technical salts or their mixtures shall be used since each of them has different characteristics related to a freezing degree. The salts can be used both solid and liquid.

Technical requirements to materials intended for winter road maintenance are defined by the Description of Technical Requirements to Materials Used for Winter Road Maintenance [3]. This document gives information concerning characteristics of materials intended to be used on the roads of national significance, requirements to their acquisition, transportation, storage, composition, preparation (mixtures) and environmental issues.

While implementing any works with chemical materials used for reducing road slipperiness or preventing pavements from icing, the following environmental requirements shall be followed [3]:

- A spreading width of chemical materials shall not exceed the width of carriageway.

- The sites for storing chemical materials shall be selected with the consideration of local relief, distance to the rivers, rivulets, lakes and other water bodies. It is prohibited to erect the storage sites of chemical materials in the water protection zones.

- When storing loose crystal salts in an open air (in stockpiles) it is necessary to prevent atmospheric precipitation from getting in. If it is not possible to install a covered structure, the stockpiles of chemical materials can be covered with waterproof materials (polyethylene sheeting, canvas, roofing paper, etc.).

- Sand-salt mixtures can only be stored on asphalt storage areas. In this case the areas shall be erected in a way to prevent the forming solution of chemical materials from leaking out of the limits of the area and from getting into surrounding soil. 
Environmental pollution caused by salts intended for winter road maintenance $\left(\mathrm{NaCl}, \mathrm{CaCl}_{2}, \mathrm{MgCl}_{2}\right.$, other) are regulated by several legal acts of Lithuania (Table 1 and 2):

- The maximum permissible concentrations (MPC) of sodium and chloride ions in drinking water are set by the Hygienic Norm HN 24:2003.

- Waste Water Treatment Regulation defines only the maximum permissible concentrations of chloride ions, likely to get into a natural environment, and the limit concentration having exceeding which it is necessary to control getting of material into environment (surface, underground water, soil).

- Seeking to determine pollution with magnesium and calcium ions, the Hygienic Norm HN 28:2003 is applied which gives criteria for the exploitation and marketing of natural mineral water and spring water.

- Based on Environmental Protection Requirements to the Treatment of Territories Contaminated with Chemical Materials, the limit values of chlorides are defined in soil, ground and underground water, however, no limitations are set for the permissible values of contamination with sodium, magnesium and calcium ions.

Table 1. Environmental pollution with salts intended for winter road maintenance $\left(\mathrm{NaCl}, \mathrm{CaCl}_{2}, \mathrm{MgCl}_{2}\right.$, other) in the legal acts of $\mathrm{Lithuania}$

\begin{tabular}{llll}
\hline Chemical material & The maximum permissible concentration*, $\mathrm{mg} / \mathrm{l}$ & $\begin{array}{l}\text { Limit value**, } \\
\mathrm{mg} / \mathrm{l}\end{array}$ & $\begin{array}{l}\text { Criterion validating the features of natural mineral water***, } \\
\mathrm{mg} / \mathrm{l}\end{array}$ \\
\hline Chloride, $\mathrm{Cl}-$ & 250 & - & 200 \\
\hline Sodium, $\mathrm{Na}+$ & 200 & - & 200 \\
\hline Magnesium, $\mathrm{Mg} 2+$ & - & 150 \\
\hline Calcium, $\mathrm{Ca}+$ & - &
\end{tabular}

Table 2. The limit values of chemical materials in soil, ground and underground water

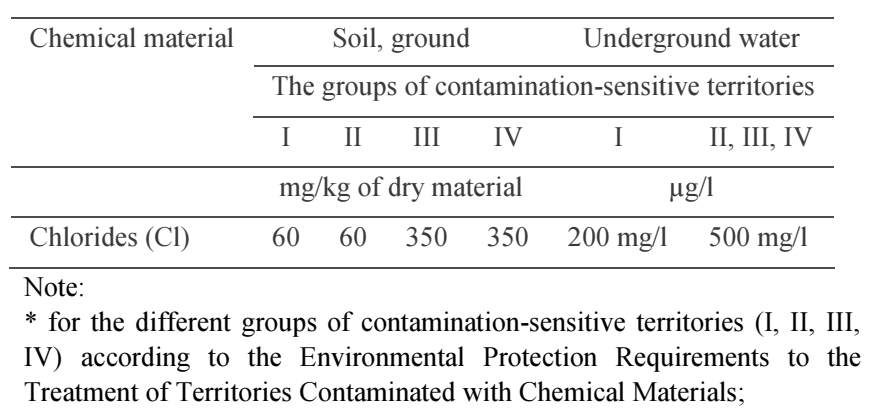

There are no legal acts regulating the amount of salts (chlorides) in flora and fauna. There are only various scientific investigations which determined the toxic values of chlorides for some plants and animals.

\section{Assessment of negative environmental impact of road salts}

Technical salts used to reduce slipperiness on roads, in spite of many negative effects, are used due to their low price, availability and efficiency. For already several decades the scientists have been interested in the consequences of their negative environmental impact. The problems caused are often discussed by the interested public also.

In winter the salts spread on the carriageway get into road environment due to splashing and spraying processes that are enhanced by wind. With the run-off the salts get into surface waters and groundwaters, thus, reaching the surrounding soil and vegetation. The amount of salts spread on the road surface depends on traffic volume. A certain amount of salt solution flows down from the surface as a run-off or is accumulated in a drainage system or road ditch, or simply flows down to both sides of the road. Another part of salt solution can be splashed by the moving tyres or lifted up by tyre treads, and the windcaught spray can be washed out from the road surface. The amount of salts in road environment reduces exponentially to the distance from the road, and their larger amounts are most frequently found in a distance closer than 10 metres from the road (Fig. 2) [5]. 


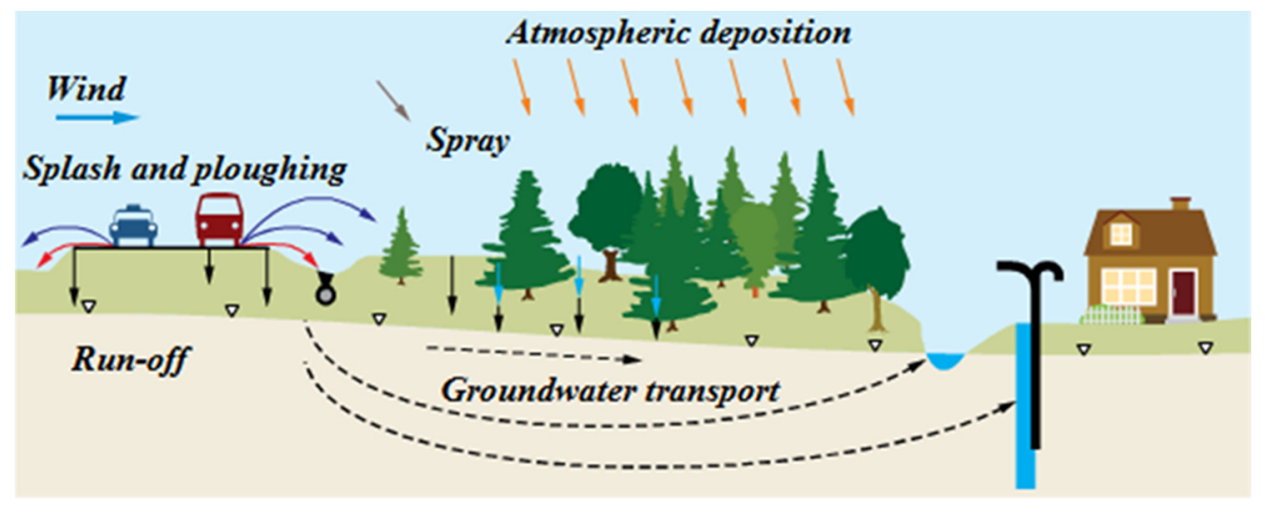

Fig. 2. A principle model and trajectory of salt migration in the environment [5]

An indirect environmental pollution is also possible where atmospheric precipitation washes the salts out from surrounding soil to the adjacent surface and groundwaters and where the salts from soil and water get into vegetation.

Another problem - corrosion of vehicles and reinforced concrete structures [6], deterioration of streets and roads caused by technical salts. When the salts dissolve in water the impact of corrosion increases more than twice. If they are used together with sand a corrosion of metal parts is even more stimulated [2].

\subsection{Impact on soil (ground)}

The largest amount of chlorine gets into soil with fertilizers, anti-slipperiness materials and precipitation. The soil does not absorb chlorine anions (further $-\mathrm{Cl}^{-}$), therefore they are rapidly washed out to deeper layers.

The spread salts get on the carriageway and roadsides first of all and directly contaminate the roadside soil in the protection zone (bio-energy regime is violated, chemical degradation if soil occurs). Besides, the environment is indirectly polluted when atmospheric precipitation or flooding water wash the salts out from soil into the surface and groundwaters.

In 2008, the scientists of the Institute of Environmental Protection determined that the background amount of $\mathrm{Cl}^{-}$in the roadside soil of the main road Vilnius-Kaunas-Klaipeda was $8.0 \mathrm{mg} / \mathrm{kg}$. In the roadside soil of other main roads (A2, A4, A14, A16) the determined background amount of $\mathrm{Cl}^{-}$was $5.0 \mathrm{mg} / \mathrm{kg}$. In the roadside soil of national roads (No. 102, No. 103, No. 107, No. 214) the determined background amount of $\mathrm{Cl}^{-}$was $3.0 \mathrm{mg} / \mathrm{kg}$ [7]. It was determined that concentration of chlorides in the upper soil layer at a 1-5 m distance from the carriageway exceeded the background values by $8-45$ times. The samples of soil for the determination of background value were taken from the relatively clean locations situated at a distance of at least 800 metres from the study road. In Lithuania, the amount of chlorides in soil is regulated neither by hygienic norms, normative documents of environmental protection nor other valid documents [7].

Under favourable spreading conditions, i.e., where the road is free from ditches, the roadsides are overgrown with only single trees, in open and even locations, and especially where the road runs on embankment, chlorides from the carriageway can overspread in larger distances, even up to $100 \mathrm{~m}$.

A salty soil damages vegetation slower than the spatter of salts. Based on the data of research carried out in Lithuania, the largest wash-out of chlorine was determined in sandy soil, and the smallest - in clayey soil [8]. The larger than $90 \mathrm{mg} / 1$ concentrations of $\mathrm{NaCl}$ in soil disturb the movement of soil bacteria, weaken the soil structure and determine more severe erosion. The soil bacteria take part in the circulation of nutrients, decompose organic material, increase soil aeration and water retention [9]. Based on 1987-1998 investigation data of the scientists of Vokè Department of Lithuanian Institute of Agriculture, the concentration of chlorine in a filtrate of unfertilized soil was $16.2 \mathrm{mg} / \mathrm{l}$ [10].

\subsection{Impact on water}

In Lithuania, the impact of road maintenance salts on the environment has undergone very few investigations; one of the first investigations was carried out in 1996 by the scientists of the Department of Roads of Vilnius Gediminas Technical University (VGTU) aiming to determine the amount of chlorides in a snow cover at the streets and in rainwater runs-off when the snow starts melting [1].

In 2003, the scientists of the Department of Environmental Protection of VGTU made the investigation of snow cover pollution with road maintenance salts on the roads of national significance of Lithuania. They have determined that after the winter season in water of the melted snow the considerably large amounts of salt-constituent materials are accumulated reaching even $13600.0 \mathrm{mg} / \mathrm{l}$ of chlorine ions and up to $1754 \mathrm{mg} / \mathrm{l}$ of natrium ions [12], [7].

The impact of road salts can be felt at a rather large distance from the road. Investigations showed that even at a 4-10 $\mathrm{m}$ distance from the road the amount of chlorides in water of the melted snow comes to $112-500 \mathrm{mg} / 1$ [13].

A lot of investigations of surface water pollution with de-icing salts have been made [14-15]. They all have determined that chloride concentration is increasing but it is lower than the maximum permissible concentration. 
Hydro-chemical investigations have determined that every spring the amount of $\mathrm{NaCl}$ in underground waters considerably increases. Continuous and repetitive surges of salt content occur since due the melting snow water with the chemicals get both into rainwater collecting wells and groundwaters [16].

The impact of road salts on surface waters is not so large as to groundwaters. Under the effect of turbulent flows, contained in surface waters, the chemical materials mix up and dilute almost immediately after getting into the flow. On the other hand, groundwaters are more sensitive to pollution as there are no turbulent factors which dilute chemical materials when runs-off leak through the soil and get into water layer [17]. Detail investigations of Neris River water, carried out by Vilnius Region Agency of the Ministry of Environmental Protection of Lithuanian, have shown that chlorides spread on streets in winter only insignificantly increase the total background of chlorides. However, for the water bodies (lakes, ponds) situated close to high-traffic streets or roads there is a real danger to be affected by road salts, thus, in these locations the monitoring of water body pollution and impact on the ecosystems must be carried out.

\subsection{Impact on vegetation}

In the territories, situated at the salt application places, salts accumulated in soils have a negative impact on the seedlings of fruit-trees, pines, poplars and firs. Salt-affected trees are more sensitive to insects, pests, drought, wind and frost [18]. It has been determined that salts accumulate on tree leaves by absorbing moisture from the air, and the leaves absorb salt solution. In salt-damaged places the process of photosynthesis and water evaporation are slower [5]. Coniferous trees, negatively affected by salts, lose their needles more rapidly. Accumulation of salts in the needles increases with their age.

Road salts, contained in soil, slow down the growth of above-ground part of plants, reduce phytomass (a mass of plants) and viability of seeds [7], [19-20].

Investigations of the resistance of grass vegetation to the toxic impact of road salts showed that the most quickly germinating plant (in 1-2 weeks) and the most resistant to the impact of toxins (up to $20 \mathrm{~g} / \mathrm{kg} \mathrm{NaCl}$ in soil) is perennial ryegrass (Lolium perenne L.), while meadow fescue (Festuca pratinsis Huds. L.) or Kentucky bluegrass (Poa pratinsis L.) germinates only in the 5th-6th week of investigation [21].

\subsection{Impact on animals}

A significantly negative impact of salts is made on the ecosystems within the road environment. Pollution of surface and groundwaters with salts causes negative impact on animals [22]. The increased salinity of water negatively affects water animals (mostly invertebrates), water plants, as well as birds and frogs feeding on them. Investigations have proven that a larger than $920 \mathrm{mg} / \mathrm{l}$ chloride concentration is toxic to daphnia, crustaceans and fish.

\subsection{Impact on vehicles}

After salts dissolve in water the impact of corrosion increases more than twice. In case they are used together with sand, corrosion of metal parts is even more stimulated.

The Tallinn scientists made field investigations of the aggressive impact of soils on vehicles. They have determined that the rapidity of corrosion during winter season is 3-7 times higher than that during other seasons [23]. Corrosion depends on temperature, precipitation and on the amount of spread salt [2].

Corrosion may impair traffic safety as it damages vehicle suspension, body, a system of brakes, electricity and fuel.

\subsection{Impact on transport structures}

In winter certain limitations are applied for spreading bridges with chemicals, though usually chlorides get on bridges from the tyres of passing vehicles. Thus, a probability of the impact of chlorides on bridge and street structures is absolutely real. It has been proven that after sodium and calcium chlorides get into concrete the component parts of cement unfreeze more actively and because of this the bonds of structural carcass of concrete weaken, together with its strength [24-25].

In summary, it should be stated that on the road sections provided with ditches (overgrown with grass) road salts make insignificant impact on the environment, however in larger cities and environmentally sensitive zones (protected areas, small water bodies situated close to road/street, etc.) it is essential to control a negative impact of salts, and having determined substantial damage to use appropriate environmental measures (alternative materials, inhibition, and the like).

\section{Possibilities for the reduction of negative impact of road salts on the environment}

For many years various scientific investigations have been made all over the world seeking to find possibilities to reduce the impact of road salts on the environment. The work was carried out in three main directions:

- Searching for alternative materials;

- Searching for various additives to conventional salts having inhibitive properties that reduce a negative impact; 
- Creating and implementing new winter road maintenance strategies and technologies to increase the efficiency of the use of road salts by applying the least possible salt amounts.

\section{Alternative materials}

A variety of materials and their mixtures (organic and inorganic) has been patented in the world having the ability to melt snow and ice: sylvinite, potassium chloride, magnesium chloride, urea, potassium acetate, calcium nitrate, ammonium hydrogen phosphate and other chemical materials that are 5-14 times more expensive than $\mathrm{NaCl}$.

Formates and acetates are effective materials characterized by weak corrosive impact (on metal and concrete) and are almost harmless to the environment. Calcium and magnesium acetates make no negative impact on water bodies and do not stimulate their overgrowing with plants since in a certain time they isolate from solutions and settle down. Calcium and magnesium ions have no negative impact on plants, even on the contrary - they increase soil fertility. These materials act especially quickly by destroying but not melting ice. The destroyed ice (not melted) is carried out from the road surface by vehicle tyres or is removed by cleaning machines. The main disadvantage of these materials is their price which compared to sodium chloride is almost 14 times higher, therefore they could be used on the very important and dangerous road sections (on viaducts, bridges, etc.) [26]. In Lithuania, formates are mostly used in airports to remove snow and ice from runways.

The least harmful from chloride salts in respect of corrosion is magnesium chloride on a basis of which the de-icing material bischofite was created. Bischofite melts ice at a $-25^{\circ} \mathrm{C}$ temperature, though it is up to 4 times more expensive than sodium chloride. It is characterized by weak negative impact on metal structures or concrete, besides, it improves soil composition and stimulates the growth of plants. However, bischofite, like technical magnesium chloride, is a hygroscopic material, i.e. absorbs moisture from the air, therefore, it is not recommended to be spread before glazed frost due to the fact that it increases the slipperiness of dry pavement (the friction coefficient value in this case may decrease by $60 \%$ ). Therefore, it is not recommended for road sections with a large gradient, in low-radius curves and in places of more intensive braking [2-3].

\section{Inhibitors}

To reduce a negative impact of salts on the environment they are inhibited with the materials improving anti-corrosive salt properties or inhibitors (i. e. reagents the small amounts of which more or less slow down the chemical processes). These are materials of inorganic or organic nature and their various combinations. Under the effect of inhibitors a coating is formed on the surface of metal or concrete product preventing it from further corrosion [27]. Besides inhibitors, for the reduction of corrosive aggressiveness of salts the other materials of inorganic or organic nature can be used: sodium hydrogen phosphate, sodium dihydrogen phosphate, calcium hydrogen- and dihydrogen phosphates (superphosphates), lignosulphonates (waste of cellulose industry), phosphates, carbonates, silicates and triethanolamine (TEA). The price of inhibitors added to sodium chloride salts is 5-14 times higher than that of sodium chloride itself.

Inhibitive additives are also contained in a commercial Safecote product which is produced on a basis of molasses (agricultural by-product obtained from the waste of sugar industry). This organic material contains mineral materials calcium, phosphorus, sulphur, chloride, sulphate, etc. This material can be blended with all road salts and their solutions, seldom used alone. Having added this material to road salts, corrosion of steel and aluminium is significantly reduced compared to corrosion using salts alone. Safecote makes a double impact on ice - melts it, helps to upraise it from the road surface and prevents from forming anew. This material decomposes biologically. If it is not possible to prepare solution, a dry salt is moistened with Safecote. In this case 1 tonne of dry salt is blended with $3.5 \%$ of Safecote (about 27 litres of material). The price of such mixture is two times higher than using conventional mixtures. Salt moistened with Safecote is effective up to $-25^{\circ} \mathrm{C}[7]$.

Another way to reduce a negative impact of salts on the environment is the use of new winter road maintenance strategies and technologies.

\section{Anti-icing strategy}

Efficiency of the anti-icing strategy was proved by the results of researches started in 1996 by the scientists of USA and other countries (investigations of different materials used on asphalt and concrete pavements under different weather conditions) [28]. It was determined that chemicals used before extreme weather conditions considerably weaken the bond between road pavement and forming ice. Even under extremely poor weather conditions (under intensive and long snowing or blizzard) up to five times facilitate and cheapen the use of chemicals after storms. The anti-icing strategy makes it possible to more efficiently ensure the highest winter service level (about 50\% cheaper) with up to 55\% lower amount of chemicals [29]. Simultaneously, a notably better quality of services is achieved (traffic safety situation is improved) and a negative environmental impact is reduced (corrosion of vehicles and structures or other impacts) [30].

\section{The warm wetted sand spreading technology}

To inconsiderable extent in Scandinavian countries and Switzerland a mixture of heated sand with hot water $\left(70-160{ }^{\circ} \mathrm{C}\right)$ in a ratio of $70 / 30 \%$ was put into practice. This technology has a longer lasting and better efficiency since hot sand has a melting effect, adheres and freezes to the surface, therefore it is not so easy to push it from the road. The experience of Scandinavian countries shows that when using this technology the amount of friction materials used for winter road 
maintenance can be reduced even by $50 \%$, besides, compared to conventional technologies (dry sand) the effect is longer up to 20 times (the friction coefficient is ensured even up to a week if pavement temperature is negative and there is no precipitation) [31].

When assessing in various aspects the above-mentioned materials used for winter road maintenance and taking into consideration their impact on the environment and price, it could be stated that for Lithuania the most acceptable alternative for roads of the highest maintenance level is the already used in practice salts of sodium and calcium chlorides. Also, it is recommended to carry out a continuous monitoring of the impact of road salts on the environment and having determined any significant impact to use appropriate environmental measures.

It is advisable for Lithuania to create programs for a more efficient use of materials by introducing modern winter road maintenance technologies and implementing a stricter quality control.

\section{Conclusions}

There are more constantly raising questions than scientific researches accomplished. A more close cooperation of all interested parties (the specialists of road maintenance, traffic safety and environmental protection) is recommended since the economically attractive solutions are necessary for solving two problems - road safety and environmental pollution.

The largest concentrations of chlorides in soil are accumulated on the right-of-way, mostly in road ditches. On sections having infiltration-grassy ditches the conventional materials (chlorides) can be used for melting ice and snow.

It is recommended before using the above-described and other alternative materials to study in more detail the requirements to their supply, transportation (since some of them are very sensitive to moisture and are transported in vacuum bags, and the like), storage, usage (technical capacity) and other peculiarities. Besides, taking into consideration their high price to carry out a cost-benefit analysis since foreign experience shows that the extent of their use is very low.

Based on the best-practice of foreign countries it is recommended to implement optimization measures for spreading salt on roads by introducing modern winter road maintenance technologies and implementing a stricter quality control. One of the ways to reduce the use of salts is the establishment of preventive road maintenance strategy. Preventive measures make it possible to more efficiently ensure the highest winter maintenance level with up to $55 \%$ lower amount of chemical materials.

\section{References}

[1] Snow and Ice Databook 2010, PIARC, $2010 \mathrm{~m}$

[2] Rimkus, A. 2003. Chloridų, naudojamų sniego ir ledo tirpinimui keliuose poveikio aplinkai ịtakojančių faktoriu analizè, in The 25th International Baltic Road Conferences Materials. Vilnius. 12 p.

[3] TRA MPŽ 13 Medžiagų, skirtų kelių priežiūrai žiemą, techninių reikalavimų aprašas. Lietuvos automobilių kelių direkcija prie Susisiekimo ministerijos Vilnius, 2013.

[4] Strèlkutė, A.; Bradulienè, J. 2013. Bišofito, naudojamo sniegui ir ledui tirpinti, poveikio augalų daigumui ir antžeminès dalies augimui tyrimas Mokslas - Lietuvos ateitis 5(4): 397-403. http://dx.doi.org/10.3846/mla.2013.63

[5] Blomqvist, G. 2001. De-icing salt and roadside environment: Air-borne exposure, damage to Norway spruce and system monitoring. PHD thesis summary. Stockholm, VTI. 5 p.

[6] Kamaitis, Z. 1995. Gelžbetoniniu tiltų būkle ir jos vertinimas. Vilnius: Technika. 182 p.

[7] Baltrènas, P.; Kazlauskienè, A.; Mikalajūnè, A. 2012. Aplinkos apsauga keliuose. Monografija. Vilnius, Technika. 383 p.

[8] Tyla, A. 1995. Cheminių medžiagų migracija ịvairiuose Lietuvos dirvožemiuose, Žemdirbystė: LŽI mokslo darbai, 50: 65-75.

[9] Rodrique, J.-P. and Comtois, C. 2008. The environmental impacts of transportation. 2013 [online]: http://people.hofstra.edu/geotrans/eng/ch8en/conc8en/ch8clen.html

[10] Tripolskaja, L. 2005. Organinès trąšos ir ju poveikis aplinkai: monografija, Akademija, Kèdainių r., 205 p.

[11] Laurinavičius, A.; Čygas, D. 1996. Cheminès medžiagos automobilių kelių ir gatvių dangų priežiūrai žiemą, Aplinkos inžinerija 2(6): 60-65.

[12] Baltrènas, P.; Kazlauskienè, A. 2009. Sustainable ecological development reducing negative effects of road maintenance salts, Technological and Economic Development of Economy 15(1): 178-188. http://dx.doi.org/10.3846/1392-8619.2009.15.178-188

[13] Kazlauskienè, A.; Baltrènas, P. 2004. Chloridu koncentracijos tyrimai sniego dangoje magistralès Kaunas - Zarasai pakelèse, in 7-toji jaunuju mokslininku konferencija „Lietuva be mokslo - Lietuva be ateities “. Vilnius: Technika, 347-354.

[14] Demers, C. L.; Sage Jr., R. W. 1990. Effects of Road De-icing Salt on Chloride Levels in Four Adirondack Streams. Water, Air, and Soil Pollution, 49: 369-373. http://dx.doi.org/10.1007/BF00507076

[15] Thunqvist, E. L. 2004. Regional increase of mean chloride concentration in water due to the application of deicing salt. Science of the total environment 325(1-3): 29-37. http://dx.doi.org/10.1016/j.scitotenv.2003.11.020

[16] Kadūnas, K.; Arustienè, J. 2010. Keliu barstymo druskos poveikio požeminiam vandeniui apžvalga: ataskaita, Lietuvos Geologijos tarnyba prie Aplinkos ministerijos, $15 \mathrm{p}$.

[17] Young, G. K.; Stein, S.; Cole, P.; Kammer, T.; Graziano, F.; Bank, F. 1996. Evaluation and Management of Highway Runoff Water Quality. U.S. Department of Transport, Federal Highway Administration. FHWA - PD - 96 - 032, Washington, D. C.

[18] Yeh, T. 2005. Protecting Trees from Peril, American Nurseryman 201(9): 47-50.

[19] Zaveckytė, J.; Kazlauskienė, A.; Ščupakas D. 2006. Žolinès augalijos daigumo tyrimai, auginant kelių priežiūros druska užterštame dirvožemyje, in 9toji jaunuju mokslininku konferencija ,,Mokslas - Lietuvos ateitis “. Vilnius: Technika, 324-330.

[20] Baltrėnas, P.; Kazlauskienè, A. 2007. Grass vegetation dynamics in soil contaminated with salt, Ekologija 53(3): 58-63.

[21] Baltrènas, P.; Kazlauskienè, A.; Zaveckytè, J. 2006. Experimental investigation into toxic impact of road maintenance salt on grass vegetation, Journal of environmental engineering and landscape management 14(2): 83-88.

[22] Mineau, P.; Brownlee, L. J. 2005. Road salts and birds: an assessment of the risk with particular emphasis on winter finch mortality, Wildlife Society Bulletin 33(3): 835-841. 
[23] Метсик, Р. Э., Холлик, А. А. 1987. Корозия автотранспорта при различных климатических и эксплуатационных условиях. Сланцевая промышленность, 7: 12-15

[24] Kamaitis, Z. 2002a. Gelžbetoninių tiltų irimas dèl armatūros korozijos. I dalis. Lauko tyrimai, Transport 17(4): $137-142$.

[25] Kamaitis, Z. 2002b. Gelžbetoniniu tiltu irimas dèl armatūros korozijos. II dalis, Transport 17(5): 163-170.

[26] Evaluation Procedures for de-icing Chemicals and Improved Sodium Chloride. 1993. Strategic Highway Research program. Washington, 34 p.

[27] Guidelines for the Selection of Snow and Ice Control Materials to Mitigate Environmental Impacts. 2007. Transportation research board. 211 p.

[28] Ketcham, S. A.; Minsk, L. D.; Blackburn, R. R.; Fleege, E. J. 1996. Manual of Practice for an Effective Anti-Icing Program: A Guide for Highway Winter Maintenance Personnel. Publication No. FHWA-RD-9-202. Army Cold Regions Research and Engineering Laboratory.

[29] Blackburn, R. R.; Bauer, K. M.; Amsler, D. E.; Boselly, S. E.; McElroy, A. D. 2004. Snow and ice control: guidelines for materials and methods. NCHRP Report, 526National Research Council, Washington, D.C.

[30] Nixon, W. A. 2002. Anti-Icers: Driving Towards Clearer Roads. Snow and Ice Manager, February 15, 2001.

[31] Vaa, T. 2004. Implementation of the new sanding method in Norway, in Transportation Research Circular EC063, Sixth International Symposium on Snow Removal and Ice Control Technology, 473-486. 